part of the total needs of consumption for which it was responsible. To achieve this it would be necessary to fix a standard economic value as a unit of money, and each association would sell its product at a price representing the economic value or "organised labour value", a kind of quotient of work done for the elaboration of a natural product and the organization and division of labour by the human spirit. By distributing these values among the manual, clerical and supervising workers belonging to the association, again according to the consumption needs for which the association is responsible, among the lenders of capital and, through the Central Economic Council, among those for whom the workers in the industry could be held communally responsible in proportion to their needs, it is suggested the root causes of conflict between employers and employed would be eradicated. Other suggestions relate to the provision of funds for new or extended economic enterprise and the issue of money so as to ensure that it is a true medium of exchange and no more, and to prevent the money in circulation exceeding the economic values created.

\section{The Kentucky Dam, Power House and Lock}

Thrs is a project of the Tennessee Valley Authority, and owing to the proximity of the site to the secondary zone of disturbance of the New Madrid earthquake of 1812, all structures forming part of the main dam were proportioned to resist seismic disturbances (Earthquake Notes, 14, Nos. 3 and 4; June 1943). The following seismic loadings were adopted: for mass structures of great rigidity an equivalent inertia. force equal to $0.05 \mathrm{~g}$. and for less rigid structures an inertia force varying from $0.06 \mathrm{~g}$. to $0.10 \mathrm{~g}$., based upon rational calculations of the dynamic action of the structure. The seismic increase in reservoir pressures was calculated by the Westergaard formula, using an earthquake acceleration of $0.05 \mathrm{~g}$. For the two large retaining walls at the end of the earth embankment at each side of the river, special investigations were undertaken to establish the proper seismic loading. An extensive programme of shaking-table tests was conducted at Leland Stanford University by Prof. L. S. Jacobsen. On the basis of these tests an equivalent inertia force of $0.18 \mathrm{~g}$. was applied to the conventional Coulomb wedge, the point of application being about $0 \cdot 60$ the height above the base. For structures sustaining hydraulic loads, the increase in overturning moment due to seismic offect was only 7 per cent, while the corresponding increase for structures such as retaining walls carrying earth loads was of the order of 35 per cent. Maps recently sent out by the State Geologist of the State of Missouri indicate large anomalies in both gravity and vertical magnetic intensity in Stoddard County, the locality of the great New Madrid earthquake of 1811. Whether there is any significance in the coincidcnce is not established, but the seismic precautions mentioned above do not appear to lack wisdom.

\section{The Gas Industry in Great Britain}

A BROADshem entitled "The Gas Industry in WarTime" (No. 210), which has been issued by Political and Economic Planning, brings up to date the report issued by PEP just before the War. It gives a concise factual account of the structure of the industry, including a note on the work of the Gas Research Board, to which gas undertakings repre. senting 76 per cent of the gas output of Great Britain are now allied. Civil defence measurcs, man-power, the effect of the War on the distribution of demand, prices, fuel economy, coal supplies, gas quality, cokeoven gas, and trends in regard to coke and by-products are briefly surveyed. In regard to the last, six committees have been set up to investigate specifie problems related to the replacement of imported by home-produced fuels, and to the most effective utilization of the latter in war-time, in particular the possibility of increasing the amount of liquid products-tar, creosote, benzene, toluene, etc.--obtained by high-temperature carbonization in gas-works and coke-ovens. Considerable progress has been made in the use of creosote pitch as a boiler and furnace fuel, although its high viscosity involves certain difficulties.

\section{Public Health in Uruguay}

IN a recent paper (Bol. Of. San. Panamericana, 22, 394 ; 1943), Dr. J. C. Mussio Fournier, formerly Minister of Public Health in Uruguay, gives the following account of public health in his country during the period 1938-42: (1) extension of preventive services; (2) better distribution of public health appropriations ; (3) considerable increase of hospital beds and in hospital construction; (4) intensification of the campaign against tuberculosis. The Health Division, Bureau of Health Examinations and de. partments of vital statistics, industrial hygiene and school prevention have been very active and the campaign against diphtheria has progressed. The appropriation for the Ministry of Health has increased 32 per cent. The present Government has spent $1,847,500$ pesos on tuberculosistreatment, 590,000 for mental patients, 3,170,000 for the Clinical Hospital, 2,774,000 for improvements in Montevideo and $1,675,000$ for rural construction. In 1937 Uruguay had only 1,055 beds for tuberculosis, a number far below present needs, as there are about 2,400 deaths annually from this cause in that country. To-day, however, Uruguay leads all Latin-American countries in the number of beds devoted to that disease.

\section{T. K. Sidey Summer-time Award}

The Royal Society of New Zealand invites applications for the T. K. Sidey Summer-time Award, consisting of a bronze medal and prize of $£ 100$, given for contributions to human knowledge by original scientific reseurch in any of the following subjects: (1) the study of light, visible and invisible, and other solar radiations in relation to human welfare; (2) the general study of radiations of every kind. Such scientific research shall not be deemed to be limited to research in modical science. Primarily the award is to be made to a New Zenlander or for work carried out in New Zealand, but the Council of the Society is at liberty to vary conditions and subject. Applicants for the award may submit either theses specially prepared or copies of published works. Applications should reach the Secretary, Royal Society of New Zealand, Victoria University College, Wellington, New Zealand, not later than January 31, 1944.

\section{Mathematical Tables and Aids to Computation}

ON January 1, I943, there appeared the first number of a new journal, entitled Mathematical Tables and Aids to Computation. It is published by the National Research Council (Washington, U.S.A.), and is to appear quarterly. The subscription is three dollars a year. The editor is Prof. R. C. Archibald, 